ECOLOGICA, Vol. 28, No 104 (2021), 487-493

https://doi.org/10.18485/ecologica.2021.28.104.1

Originalni naučni rad

UDC: 341.123:005.745“2021“

502.131 .1

\title{
Results of 26th United Nations Climate Change Conference (COP26) held in Glasgow
}

\section{Rezultati 26. Konferencije Ujedinjenih Nacija o promeni klime održane u Glazgovu}

prof. dr Mario Lukinović ${ }^{*}$, PhD Lucia Škvareninová ${ }^{2}$, MSS, DBA, prof. dr Larisa Jovanović3

${ }^{1}$ Faculty of Law, Union University, 36 Marshal Tolbukhin Boulevard, Belgrade, Serbia

2Department of Landscape Management, Faculty of Forestry and Wood Technology, Brno, Czech Republic

${ }^{3}$ Alfa Univerzitet, 3 Palmira Toljatija, Belgrade, Serbia

${ }^{*}$ Corresponding author

Received: 05.09.2021, Accepted: 08.11.2021.

\begin{abstract}
The change in the way of life of modern man caused by industrialization and the rapid growth of the population have influenced the anthropogenic and technogenic activities to have a devastating effect on the environment like never before. Climate change as a direct consequence of these activities occurs due to the emitions of greenhouse gases. In an effort to slow global warming and mitigate the catastrophic consequences for the environment since 1995, the international community has brought together decision-makers, representatives of the international community, the economy and civil society, as well as experts on climate change. After a one-year delay due to the COVID-19 pandemic, the 26th annual UN Conference on Climate Change was held in Glasgow. The paper presents the results of the work of this Conference as well as a brief overview of the most important decisions and activities in the international and national context.
\end{abstract}

Keywords: COP26, climate change, international community, industrialization, greenhouse gases, global warming, catastrophic consequences, mitigation, sustainable development

Sažetak: U Promena načina života savremenog čoveka izazvana industrijalizacijom i snažan porast populacije uticali su da antropogeni i tehnogeni aktivnosti va kao nikada ranije deluju pogubno na životnu sredinu. Klimatske promene kao direktna posledica tih aktivnosti nastaju usled emisije gasova sa efektom staklene bašte. Međunarodna zajednica u pokušaju da uspori globalno zagrevanje i ublaži katastrofalne posledice po životnu sredinu od 1995. godine u okviru redovnih godišnjih konferencija Ujedinjenih nacija o klimatskim promenama na jednom mestu okuplja donosioce odluka, predstavnike međunarodne zajednice, privrede i civilnog društva, kao i eksperte na temu klimatskih promena. Nakon jedne godine odlaganja zbog pandemije COVID-19 u Glazgovu je održana 26. Konferencija UN o klimatskim promenama. U radu su predstavljeni rezultati rada ove Konferencije kao i kratak pregled najznačajnijih odluka i aktivnosti u međunarodnim i nacionalnim okvirima.

Ključne reči: COP26, klimatske promene, međunarodna zajednica, industrijalizacija, gasovi staklene bašte, globalno zagrevanje, katastrofalne posledice, ublažavanje, održivi razvoj.

\footnotetext{
1orcid.org/0000-0003-1470-5872, e-mail: lukinovicmario@gmail.com

${ }^{2}$ e-mail: lefong@lefong.sk

${ }^{3}$ orcid.org/0000-0002-1840-819X, e-mail: larisa.jovanovic@alfa.edu.rs
} 


\section{INTRODUCTION}

Thanks to the favorable climatic conditions, the human race managed to prosper and become dominant on the planet. A man has relied heavily on biodiversity in his progress, drawing from it the strength of his progress (Lukinović, Jović, 2021). Although the Earth has a constant size, its climate is not stable due to the very small eccentricity of its orbit around the Sun. Atmosphere (air), hydrosphere (water), cryosphere (ice and permafrost), lithosphere (earth's upper rocky layer) and biosphere (living beings) are constantly interacting with each other making the climate variable (Grasl, 2011). Climate change has a strong impact on ecosystems. The modern way of life and today's population size affect the pollution of water, air and land, generating huge amount of waste substances, calling into question not only human health and well-being, but also the very survival of civilization. Carbon dioxide is the most significant cause of global warming with a $77 \%$ share in increasing the greenhouse effect, and its current concentration due to anthropogenic effects is the highest in the last 650,000 years (Jovanović, Munitlak Ivanović, 2015). Its increase, together with other greenhouse gases, leads to the disruption of the global climate system.

\section{FIGHT AGAINST CLIMATE CHANGE AND ACHIEVED RESULTS}

Given that national and international law have limited scope, and that the prescribed legal norms are generally not dynamic enough to be an adequate instrument for mitigating and combating climate change, the international community has made efforts to regulate this issue (Lukinović, Jović, 2021). "Global solutions are needed to solve global problems" (COP 26 Coalition, 2021). These efforts have led to the adoption of the United Nations Framework Convention on Climate Change (UNFCCC) aimed at stabilizing greenhouse gas concentrations. The Convention was adopted and signed at the World Summit in Rio de Janeiro in 1992, and entered into force in 1994 when it was ratified by the signatory states. Since its adoption until today, the parties to the Convention have been trying to find a way to stabilize the concentrations of greenhouse gases $\left(\mathrm{CO}_{2}, \mathrm{~N}_{2} \mathrm{O}, \mathrm{CH}_{4}, \mathrm{HFCs}\right.$, PFCs, and $\mathrm{SF}_{6}$ ) in the atmosphere "at a level that would prevent negative anthropogenic impacts on the climate system" (Article 2). Although environmental awareness has been awakened on a global level, all previous conferences are taking place in the shadow of the antagonism between the European Union and small island states on the one hand, and China, the
United States, Brazil and India on setting the necessary goals. Different economic interests of countries have led to different perspectives in relation to emission limits and especially the inclusion of the so-called historical pollution in the obligations of developed countries (Todić, Grbić, 2014).

The activities and objectives set out in the Convention should reduce the rate of atmospheric warming "in a time frame sufficient to allow the natural adaptation of ecosystems to climate change, and not to jeopardize food production, but to enable sustainable development". At the United Nations Conference on Climate Change in Paris, the Paris Agreement was signed, which many marked as a turning point in creating the future of the planet, considering that it is the first legally binding act. Currently, the average temperature in the world is 0.85 degrees higher than the temperature in the preindustrial period, climatologists estimate that an increase in temperature of $2^{\circ} \mathrm{C}$ would be an introduction to the disastrous warming. Therefore, as a long-term strategic goal of this Agreement, the goal is to keep the increase in global temperature well below $2^{\circ} \mathrm{C}$, with a tendency to limit this growth to $1.5^{\circ} \mathrm{C}$ (Lukinović et al., 2016).

Based on the results of monitoring and research within the Global Climate Observation System of the World and World Climate Program, the third report of the International Panel on Climate Change (IPCC) identified Five Integrative Reasons for Concern (RFC). By assessing scientific, technical and socioeconomic information relevant to understanding the scientific basis of the risks of anthropogenic climate change, the potential impacts of these changes and options for climate change mitigation and adaptation to changed climate conditions, the impacts and / or risks for each RFC are presented. Unique and endangered systems (coral reefs, the Arctic and the population living there, mountain glaciers and biodiversity centers) have been identified as the first cause for concern. Another reason for concern is an extreme meteorological event (heat waves, heavy rains, droughts, forest fires and floods in the coastal area). The third reason is the distribution of impacts (risks and impacts that particularly affect groups whose vulnerability or exposure is expressed due to greater exposure to the physical aspects of climate change). Fourth are global accumulated impacts (material damage, degradation and loss of ecosystems and biodiversity). Five reasons for concern are large-scale individual events (changes in systems caused by global warming: disintegration of the Greenlandic and Antarctic ice sheets, etc.) (IPCC, 2018). 


\title{
How the level of global warming affects impacts and/or risks associated with the Reasons for Concern (RFCs) and selected natural, managed and human systems
}

Five Reasons For Concern (RFCs) illustrate the impacts and risks of different levels of global warming for people, economies and ecosystems across sectors and regions.

Impacts and risks associated with the Reasons for Concern (RFCs)
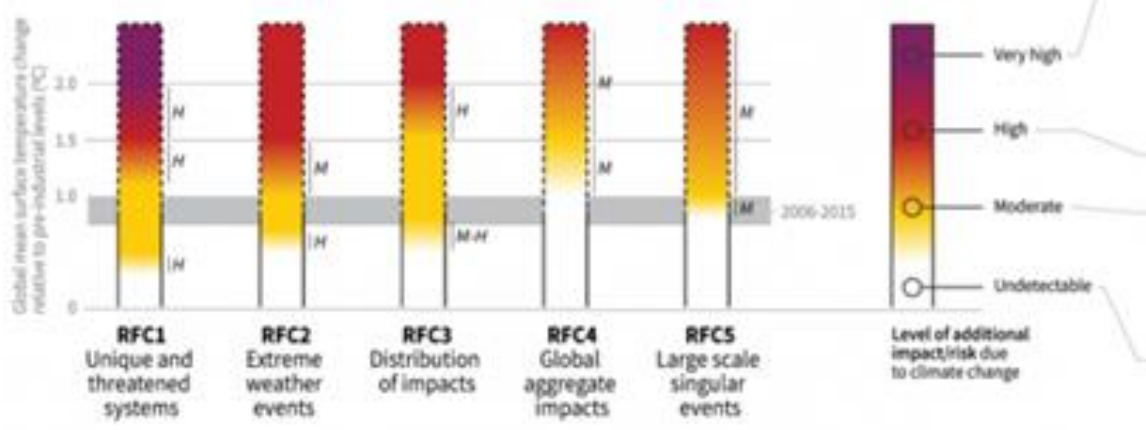

\author{
Purple indicates very high \\ risks of severe impacts/risks \\ and the presence of \\ significant irreversibility or \\ the persistence of \\ climate-related hazards, \\ combined with limited \\ ability to adapt due to the \\ nature of the hazard or \\ impacts/risks. \\ Red indicates severe and \\ widespread impacts/risks. \\ Vellow indicates that \\ impacts/risks are detectable \\ and attributable to climate \\ change with at least medium \\ confidence. \\ White indicates that no \\ impacts are detectable and \\ attributable to climate \\ change.
}

Impacts and risks for selected natural, managed and human systems

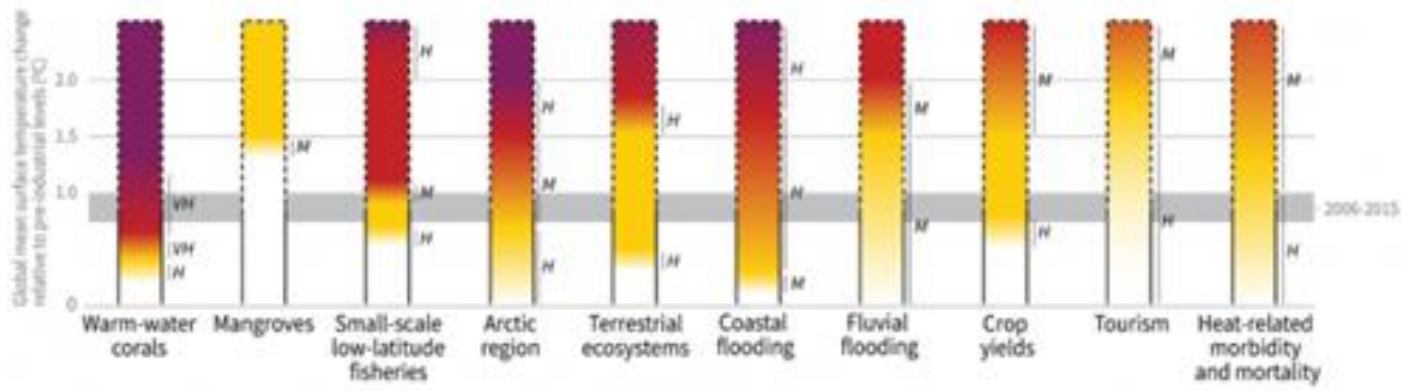

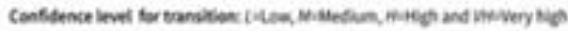

Figure 1. How the level of global warming changes the impacts and / or risks associated with Reasons for concern (RFC) and selected natural, controlled and social systems Source: IPCC, (2018)

The conference was preceded by the one held in Madrid in 2019, after Chile canceled the host due to large civil protests. Like all conferences held after 2015 , it took place in the shadow of the Paris Conference and the agreements reached there. One of the goals from the Paris Agreement, the implementation of which has not yet begun, is Art. 6 which refers to the implementation of the guidelines for the mechanism of voluntary cooperation.

In the period between these two Conferences, the Republic of Serbia adopted the Law on Climate Change ("Official Gazette of the RS", No. 26/2021). By adopting this law, Serbia has fulfilled its obligation under the UN Framework Convention on Climate Change and the Paris Agreement. The introd- uction of this Law provides the conditions for the establishment of a system to reduce GHG emissions in a cost-effective and cost-effective manner. Quantitative assessment of greenhouse gas emissions can only be achieved through better collection of data and information on climate change, which is why the concept of a national Monitoring, Reporting and Verification (MRV) system is needed to define the roles and responsibilities of all actors in the process (Klimatske promene, 2021). At the Berlin Process Summit held in Sofia in 2020, the countries of the Western Balkans committed themselves to implementing the "Green Agenda for the Western Balkans" (Vasilkov et al., 2021). The signatory states (including the Republic of Serbia) have comm- 
itted themselves to implement measures in the field of prevention of climate change and pollution, development of energy, transport and circular economy, as well as development of biodiversity, sustainable agriculture and food production. For the five pillars of the Green Agenda are marked: Decarbonisation: climate, energy, mobility (Clean Energy Transition), Circular economy: sustainable production and consumption, Depollution: air, water and soil, Sustainable food systems and rural areas, Biodiversity: protection and restoration of ecosystems (COM, 2020).

The adoption of this Law is a big step towards the development of harmonized environment with the reduction of the impact on climate change, but in order to achieve the goals proclaimed by it, it is necessary for state bodies and organizations to adopt appropriate sectoral policies and measures within their competence. The law specifies the documents whose adoption is necessary in order to achieve the set goals: the Low Carbon Development Strategy, the Action Plan for the implementation of the strategy and the Program for Adaptation to Changed Climate Conditions.

\section{ANALYSIS OF THE RESULTS OF THE UNITED NATIONS CONFERENCE IN GLASGOW}

Due to the global SARS COV-2 virus pandemic, the conference was held a year later, in 2021, in Glasgow, instead of in November 2020. The Conference was hosted by the United Kingdom in partnership with Italy. The Republic of Serbia was the co-chair of this conference. The conference is open. The primary goal of the Glasgow Conference is to create a framework for accelerated global action to address the climate crisis.

After several days of negotiations, a compromise agreement was embodied in the Agreement, which was signed by all 197 members of the United Nations. In relation to the proposed draft agreement, the adopted one caused disappointment not only on the side of environmental activists, but also of a significant number of countries. The draft called for the "phasing out" of coal-fired power generation without the use of any $\mathrm{CO}_{2}$-reducing technology, such as carbon storage. Under the pressure of certain countries, especially India and China, the wording "gradual abolition" is being relaxed, and in the adopted Agreement, the wording "gradual reduction" has been changed.

As never before, impressions of this climate conference are divided, and while some celebrate the success, noting that the signing of the Agreement is a big step forward towards "the beginning of the end of climate change", because it is the first international agreement on gradual coal reduction and roadmap for limiting global warming to $1.5^{\circ} \mathrm{C}$. Pessimists, on the other hand, believe that humanity is "knocking on the door of the climate catastrophe" and that an urgent transition to zero is necessary.

The acuteness of the situation mobilized environmental movements to action. For the needs of urgent reactions and pressure on the participants of the Conference in Great Britain, the Coalition COP 26 was formed, which consists of 151 international environmental organizations, civil society and 58 local members. This Coalition, like most environmental activists, assessed the results of the Conference embodied in the Agreement negatively (COP 26 Coalition, 2021). An independent scientific analysis that monitors progress towards the globally agreed goal of keeping warm - Climate Action Tracker has published a report according to which the greenhouse gas emissions that heat the planet in 2030 will still be twice as high as necessary to maintain the temperature rise below 1.5 degrees Celsius and that the projected heating by 2100 is $2.7^{\circ} \mathrm{C}$. However, these forecasts are significantly more favorable compared to the projections made by Climate Action Tracker on the eve of the Paris Conference in 2015, when it was estimated that we are moving towards a warming of $3.6^{\circ} \mathrm{C}$ (Climate Action Tracker, 2021).

Devastating heat waves, major droughts and floods are particularly affecting developing countries. Better weather and climate observations can significantly help in the long-term predictability of climate change and influence their reduction. Therefore, the World Meteorological Organization, U.N. Development Program and the U.N. Environment Program presented the Systematic Observations Finance Facility - SOFF as part of the Glasgow Conference. The goal of this program is to adequately monitor time and collect data for better climate adaptation and resilience of developing countries and their better preparedness for possible climate catastrophes ( WMO, 2021).

\section{THE ROLE OF EARTH OBSERVATION SATELLITES PROMOTED AT COP26}

Arctic is one of the fastest warming place on the Earth. Over the last decade, the Greenland Ice Sheet has shown rapid change, characterized by rapid thinning along the margins, accelerating outlet glaciers and overall increasing mass loss (European Space Agency, 2021a). Greenland's ice sheet, the biggest in the world behind Antarctica, is melting at the average rate of 270 billion tons a year and it is losing ice at an accelerated level since the 1990's. In 2019, as a result of extreme weather led to record- 
breaking levels of ice melting and the runoff was about 527 billion tons (USA today, 2021). Over the last decade global sea levels rise by 1 centimeter. Scientists predict the sea level will rise nearly a foot higher by the end of the 21st century.

Climate change is an ongoing process, that has negative consequences on the global population. Nobody can be taken out of from these chain actions, happening around us on a daily basis. The most vulnerable group of people are local communities. For instance, as a result of ice sheet melting in Arctic, the local arctic hunters are vanishing. Their living conditions and lives are endangered. The same situation applies for local communities in the Amazon forests, who are the victims of an extreme deforestation process, which causes the loss of their original territories.

Thanks to existing technologies such as satellites, scientists can obtain periodical satellite records and observe development of global climate change.

During the 12-day, Glasgow-based summit, European Space Agency (ESA) highlighted the crucial role Earth observation satellites play in understanding the evolving climate and supporting effective action (European Space Agency, 2021b). At the COP26, high-level talks and negotiations primarily led to accelerate the actions to achieve the Paris Agreement goals, agreed in 2015. It is important to achieve the temperature rise below 2 Celsius degrees, ideally $1.5^{\circ} \mathrm{C}$.

Observation of space plays a key role to monitor important changes on our planet - GHG emission levels, rising sea levels, wild fires, deforestation, etc. ESA promotes sustainable and green future development through various initiatives promoted at COP26, e.g. ESA's Climate Change Initiative.

\section{THE VOICE OF THE GLOBAL SOUTH}

Representatives from African countries raised their voice to express disappointment of industrialized countries not fulfilling the promise in climate financing. In 2020 developing countries were supposed to receive $\$ 100$ billion, but it won't be reached up until 2023. At the same time, negotiations about how to deal with loss and damage among the nations in the southern hemisphere suffering from climate change were not successful. While G-77 and China proposed the establishment of such fund to compensate the losses in affected areas, major players such as U.S., France and Japan blocked proposal.

From the perspective of poor countries, the results of COP26 were disappointing, slow, insuffic- ient and agreements taken at the conference seems to have not binding character. The main argument is the helplessness of poor nations to cope with climate change consequences by themselves, that are already taking place such as floods, droughts, etc. Developing countries expect the rich and industrialized North to take a real action with financial support up to trillions USD helping to resolve the situation in the forthcoming future.

On one hand, rich nations already went through the process of industrialization, especially since more than one hundred years ago until recently; while countries as India, China or African continent would like to enjoy same possibilities of development as Western powers, but without use of coal or fossil fuels, it is impossible. There is a significant gap between expectations of the rich countries and Global South. Understandably, the least developed countries are unable to keep the promises to take rapid actions in fighting the climate change without help.

\section{COMMON DECISION TO REDUCE THE USE OF COAL}

Coal supplies over one-third of global electricity generation and plays a crucial role in industries such as iron and steel (International Energy Agency, 2021). It is believed to be the greatest single contributor to anthropogenic climate change and likely to be significant in the future, if world-wide governments won't change their policies. This chart shows per capita $\mathrm{CO}_{2}$ emissions from coal, oil, gas, flaring and cement, measured in tones of $\mathrm{CO}_{2}$ per year [17] (Our world in data, 2021a). Global $\mathrm{CO}_{2}$ emissions from coal reached 1.79 tones of $\mathrm{CO}_{2}$ emissions in 2020, which is the highest level among other fuels.

For the first time in the history of COP, decision to globally reduce the use of coal as a source of energy was achieved. For China and India, two countries being heavily dependent on coal, proposal with the term "phase out" had to be replaced by the phrase "phase-down" in the context of using coal, which was also recommended by small island countries. India opposed hard targets on phasing out coal as well as other fossil fuels like gas and oil, but was particularly opposed to the singling out of coal alone, which is still among the key sources of energy for developing nations (Hindustan times, 2021). Figure 2 shows the worldwide coal demand and its significant drop in first quarter of 2020 by 11\% (International Energy Agency, 2021) as a result of lockdowns and Covid-related situation. China and India remain the two leading countries in consumption of coal. 


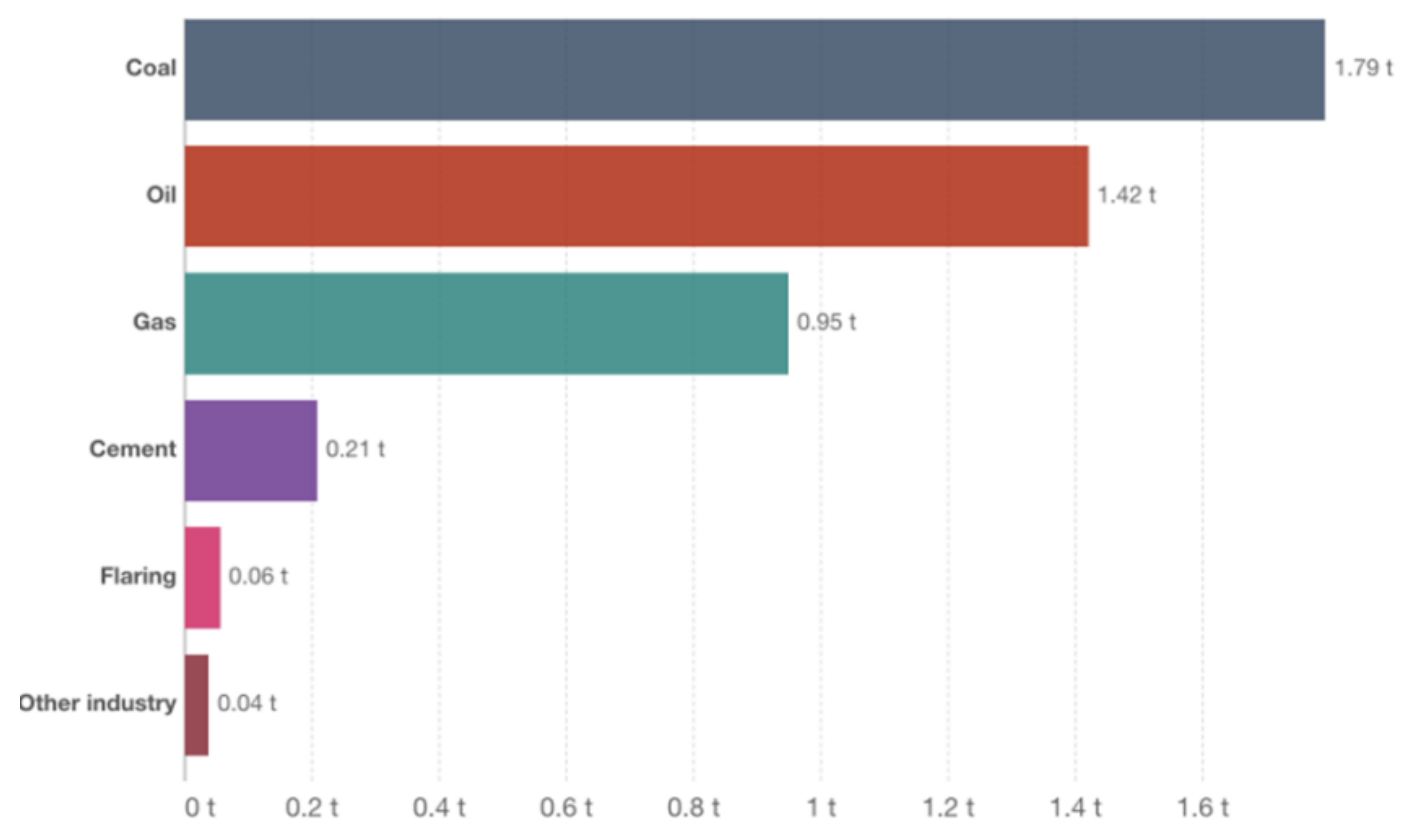

Figure 2. Per capita $\mathrm{CO}_{2}$ emissions by fuel type in the world, 2020 Source: Our world in data (2021b)

$\%$

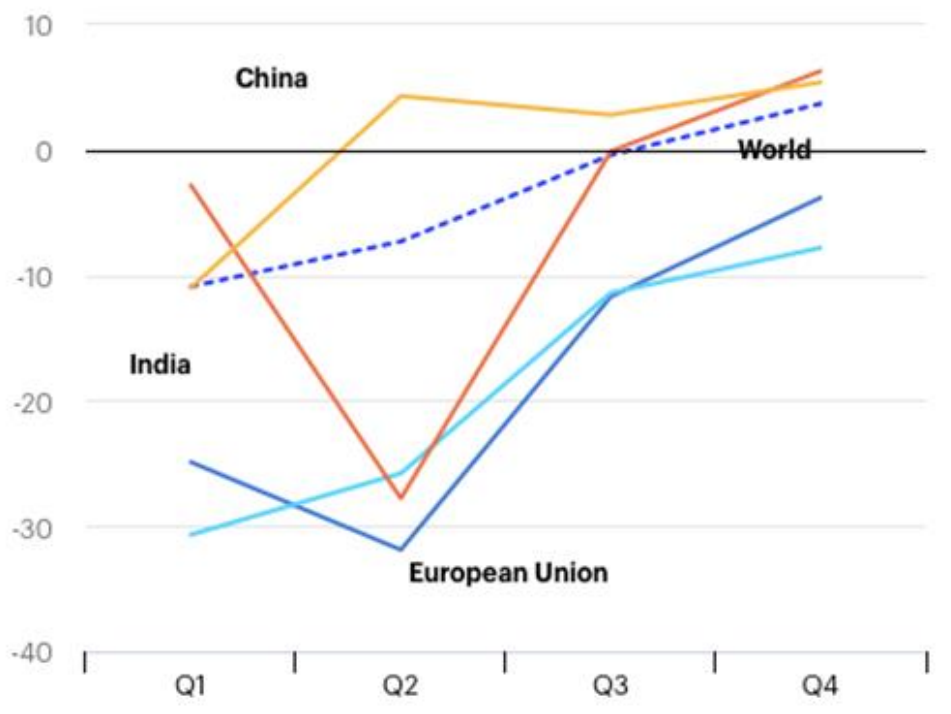

IEA. All Rights Reserved

- China India United States European Union World

Figure 3. Year-on-year quarterly change of coal consumption by region, 2020. Source: International Energy Agency (2021) 


\section{CONCLUSION}

It is never too late to take an action. Unless the global community works together to achieve common goals agreed at the conference, not much would be done individually. The COP26 proved different positions and capabilities of industrialized and poor countries, especially from financial perspective. Global South demands greater financial assistance from rich countries in order to deal with the consequences of climate change. Promotion of lowcarbon energy sources is also a matter of financial capabilities. Stronger international cooperation with binding climate targets will be needed in the next conference.

\section{LITERATURA / REFERENCES}

[1] Climate Action Tracker, (2021). https://climateactiontracker.org/

[2] COM, (2020). Guidelines for the Implementation of the Green Agenda for the Western Balkans Accompanying the Communication from the Commission to the European Parliament, the Council, the European Economic and Social Committee and the Committee of the Regions An Economic and Investment Plan for the Western Balkans $\{C O M(2020) 641$ final\}.

[3] COP 26 Coalition, (2021). https://cop26coalition.org/about/the-coalition/

[4] European Space Agency, (2021a). https://climate .esa.int/en/projects/ice-sheets-greenland/

[5] European Space Agency, (2021b). https://climate .esa.int/en/news-events/COP26/

[6] Grasl, H. (2011). Klimatske promene, Laguna, Beograd, str. 9.

[7] Hindustan times, (2021). https://www.hindustantimes.com/indianews/didnt-introduce-phase-down-in-cop-26statement-clarifies-india-101637196023549.html

[8] International Energy Agency, (2021). https://www.iea.org/fuels-and-technologies/coal

[9] IPCC, (2018). Intergovernmental Panel on Climate Change. Summary for Policymakers. In: Global Warming of $1.5^{\circ} \mathrm{C}$. An IPCC Special
Report on the impacts of global warming of $1.5^{\circ} \mathrm{C}$ above pre-industrial levels and related global greenhouse gas emission pathways, in the context of strengthening the global response to the threat of climate change, sustainable development, and efforts to eradicate poverty [Masson-Delmotte, V., P. Zhai, H.-O. Pörtner, D. Roberts, J. Skea, P.R. Shukla, A. Pirani, W. Moufouma-Okia, C. Péan, R. Pidcock, S. Connors, J.B.R. Matthews, Y. Chen, X. Zhou, M.I. Gomis, E. Lonnoy, T. Maycock, M. Tignor, and T. Waterfield (eds.)]

[10] Jovanović, L., Munitlak Ivanović, O., (2015). Osetljivost privrede na klimatske promene, Ecologica, 22 (78), 117-122.

[11] Klimatske promene, (2021). Usvojen Zakon o klimatskim promenama, Srbija i klimatske promene, https://www.klimatskepromene.rs/izdvajamo/usv ojen-zakon-o-klimatskim-promenama/

[12] Lukinović, M., Jovanović, Đ., Jovanović, L. (2016). Rešavanje klimatskih promena i analiza rezultata Konferencije UN u Parizu, Ecologica, 23(82), 153-160.

[13] Lukinović, M. Jović, V., (2021). Ekološko pravo, Pravni fakultet Univerziteta Union, Službeni glasnik, Beograd.

[14] Our world in data, (2021a). https://ourworldindata.org/emissions-by-fuel

[15] Our world in data, (2021b). https://ourworldindata.org/co2-and-othergreenhouse-gas-emissions

[16] Todić, D., Grbić, V., (2014). Zemlje u razvoju i politika u oblasti klimatskih promena, Međunarodni problemi, 1-2, 160-182.

[17] USA today, (2021). https://eu.usatoday.com/ story/news/world/2021/11/03/greenlands-icesheet-melting-global-seal-level/6242560001/

[18] Vasilkov, Z., Petrović, S., Vuković, J., Lazić, D., Damnjanović, A., (2021), Zeleni dogovor Evropske unije i Zelena agenda za Zapadni Balkan: nove smernice za suočavanje sa izazovima zaštite životne sredine, Ecologica, 28(104).

[19] WMO, (2021). https://public.wmo.int/en/media /news/wmo-activities-cop26 